\title{
PENGARUH TATA KELOLA PERUSAHAAN TERHADAP PROFITABILITAS PADA PERUSAHAAN YANG TERDAFTAR DI BURSA EFEK INDONESIA
}

\author{
Fariz Satriadi, Mas yhuril Amri Bagas kara, Titin Pranoto, Luciana Haryono \\ Sekolah B isnis dan Ekonomi - Universitas Prasetiya Mulya \\ BSD City Kavling Edutown I.1 , Jl. BSD Raya Utama, BSD City, Tange rang 15339
}

Keywords:

Firm age, good corporate governance, leverage, and profitability

\section{Kata Kunci:}

Umur perusahaan, tata kelola perusahaan, leverage, profitabilitas

Cores ponding Author: satriadifariz@gmail.com

\begin{abstract}
This research is aimed to analyze the influence of good corporate governance to company's profitability. This research is based on the previous research that is done by Zabri, Ahmad and Wah (2016). Aside from board size and independent commissioner's composition, this research added few variables which are; board meeting, audit committee size and audit committee meeting with firm age and leverage as the control variables. Profitability is measured by return on asset (ROA) and return on equity (ROE). Samples of this study consist of 170 non-financial listed firms during 2012 - 2016. Multiple regressions were used to test the hyphotheses. The result of this research has showed that good corporate governance gives significant influence to the profitability of the companies located in Indonesia.
\end{abstract}

\section{SARI PATI}

Penelitian ini bertujuan untuk menganalisa pengaruh penerapan tata kelola perusahaan terhadap profitabilitas perusahaan. Penelitian ini mengacu pada penelitian Zabri, Ahmad, dan Wah (2016) yang meneliti pengaruh penerapan tata kelola perusahaan terhadap prof itabilitas perusahaan di Malaysia dengan menambahkan beberapa variabel selain ukuran dewan direksi dan komposisi komisaris independen antara lain; frekuensi rapat dewan komisaris, ukuran komite audit, frekuensi rapat komite audit umur perusahaan dan leverage sebagai variabel independen. Sedangkan, profitabilitas perusahaan diukur dengan return on asset (ROA) dan return on equity (ROE). Sampel yang digunakan dalam penelitian ini adalah 170 perusahaan non keuangan yang terdaftar di Bursa Efek Indonesia dengan tahun observasi 2012 - 2016. Regresi berganda digunakan untuk menguji hipotesisi. Hasil penelitian ini menunjukkan bahwa penerapan tata kelola perusahaan memberikan pengaruh signifikan terhadap profitabilitas perusahaan di Indonesia. 


\section{Pendahuluan}

Tata kelola perusahaan bukanlah suatu hal baru di dunia maupun Indonesia. Tata kelola perusahaan menjadi suatu bagian yang tidak dapat terpisahkan di dalam suatu perusahaan. Hal ini berawal dari kasus Enron yang menggemparkan dunia perekonomian. Sukamulja (2005, CNNfn Transcript 2002) yang menyatakan bahwa Enron telah menyadarkan masyarakat Amerika dan dunia bahwa tata kelola perusahaan sangat diperlukan sebagai barometer akuntabilitas suatu perusahaan. Kemudian, Indonesia mulai sadar terhadap pentingnya tata kelola perusahaan karena krisis yang melanda Indonesia pada tahun 1997. Salah satu cara penyelesaian krisis adalah bantuan dari International Monetary Fund (IMF) dengan syarat perjanjian tentang perbaikan dan peningkatan praktik tata kelola perusahaan (Lukviarman, 2016). Mulailah terbentuk suatu komite yang memperhatikan tata kelola perusahaan, yaitu Komite Nasional Kebijakan Corporate Governance (KNKCG) pada tahun 1999. Setahun setelahnya, KNKCG menghasilkan kode etik untuk pelaksanaan tata kelola perusahaan melalui "Code for Good Corporate Governance”.

Pemerintah semakin giat memperhatikan pentingnya penerapan tata kelola di setiap perusahaan. Hal ini terlihat dari dibuatnya The Indonesia Corporate Governance Manual oleh International Finance Corporation dan Otoritas Jasa Keuangan (IFC dan OJK) (2014). Manual ini merupakan hasil dari sebuah program yang dibuat oleh IFC dan OJK. Program tersebut dimulai dan diimplementasikan dari tahun 2012. Program yang dibuat oleh IFC dan OJK bertujuan untuk membuat sebuah pedoman bagi seluruh perusahaan dalam upaya menerapkan tata kelola perusahaan. Hal ini yang memperlihatkan keseriusan pemerintah Indonesia dalam meningkatkan penerapan tata kelola perusahaan. Keseriusan pemerintah dalam memperhatikan pentingnya penerapan tata kelola perusahaan juga dapat terlihat dari Salinan Surat Edaran Otoritas Jasa Keuangan Nomor 32 / POJK.04 / 2015 tentang "Pedoman Tata Kelola Perusahaan Terbuka" (OJK, 2015). Salinan surat edaran ini berisi mengenai kewajiban seluruh perusahaan terbuka untuk menerapkan tata kelola perusahaan dengan baik. Selain itu, salinan ini juga berisi mengenai pedoman bagi setiap perusahaan dalam menerapkan tata kelola perusahaan. 
IFC dan OJK (2014) menyatakan bahwa tata kelola perusahaan berfungsi untuk mengontrol struktur dan proses bisnis perusahaan yang berlandaskan tanggung jawab, transparan, akuntabilitas, dan adil terhadap setiap pemangku kepentingan perusahaan. Selain itu, manfaat tata kelola perusahaan adalah membantu perusahaan dalam meningkatkan efisiensi dalam sektor operasionalnya, memiliki peluang lebih besar untuk dapat masuk ke dalam pasar modal, memiliki reputasi yang baik dalam dunia perekonomian, dan memberikan kesempatan kepada perusahaan dalam membantu meningkatkan perekonomian suatu negara (IFC dan OJK, 2014). Manfaat tata kelola perusahaan dalam mengontrol keadilan di dalam perusahaan dinyatakan oleh Cadbury (2002, dalam Lukviarman 2016) bahwa tata kelola perusahaan memperhatikan keseimbangan antara tujuan ekonomi dan sosial serta tujuan individu dengan kelompok. Pernyataan ini memperlihatkan bahwa tata kelola perusahaan mencegah terjadinya timbul permasalahan agar tujuan perusahaan akan lebih diutamakan dibandingkan tujuan pribadi.

Perusahaan dapat menerapkan tata kelola dengan cara mengikuti pedoman yang telah dibuat OJK (2015), yaitu Salinan Surat Edaran Otoritas Jasa Keuangan Nomor 32 / POJK.04 / 2015. Menurut peraturan OJK tersebut, perusahaan wajib memiliki dewan komisaris independen minimal sebanyak satu orang. Keberadaan dewan komisaris independen di dalam perusahaan merupakan suatu hal yang penting karena dewan komisaris independen berfungsi melakukan pengawasan dan memberikan nasihat kepada direksi, serta memastikan perusahaan telah menerapkan tata kelola (KNKG, 2006). Selain itu, dewan komisaris independen dapat meningkatkan efektivitas perusahaan karena dewan komisaris independen akan mencegah terjadinya tindakan oportunistik yang dilakukan dewan direksi (Jensen dan Meckling, 1976).

Dewan komisaris independen tidak dapat mengambil keputusan yang berhubungan dengan operasional perusahaan (KNKG, 2006). Maka dari itu, dibutuhkan dewan direksi yang berfungsi untuk mengambil keputusan dalam mengelola perusahaan (IFC dan OJK, 2014). Berdasarkan peraturan OJK, perusahaan wajib memiliki dewan direksi minimal sebanyak dua orang. Yasser (2011) menyatakan bahwa rapat butuh diadakan untuk mencari solusi dari masalah yang dialami oleh perusahaan dan mengevaluasi operasionalisasi perusahaan. Peraturan OJK menyatakan bahwa setiap 
perusahaan harus mengadakan rapat (rapat direksi, rapat komisaris, maupun rapat komite yang membantu kinerja komisaris) minimal empat kali dalam setahun. Semakin banyak rapat yang dilakukan dapat membuat terjadinya diskusi lebih banyak sehingga dapat menemukan solusi lebih baik untuk menyelesaikan masalah yang terjadi (Javed, Iqbal, dan Hasan, 2006). Namun Johl, Kaur, dan Cooper (2015) menyatakan bahwa semakin banyak rapat akan menimbulkan biaya yang dapat menurunkan produktivitas perusahaan (Johl, Kaur, dan Cooper, 2015).

Untuk menunjang kinerja dewan komisaris dalam mengawasi pengelolaan perusahaan dibutuhkan adanya komite penunjang. Salah satu komite penunjang adalah komite audit. Komite audit berfungsi untuk membantu dewan komisaris untuk memastikan semua prosedur yang berhubungan dengan auditor, seperti penyajian laporan keuangan, pengendalian internal perusahaan, dan pelaksanaan audit internal maupun eksternal dapat berjalan dengan lancar dan wajar (IFC dan OJK, 2014). Peraturan OJK menganjurkan perusahaan memiliki anggota komite audit minimal sebanyak tiga orang. Semakin banyak anggota komite audit dapat meningkatkan efektivitas komite audit karena sumber daya dalam mengawasi pengelolaan perusahaan juga semakin banyak (Karamanou dan Vafeas, 2005).

Penerapan tata kelola yang baik dapat meningkatkan profitabilitas pada suatu perusahaan. Hal ini dikemukakan oleh beberapa penelitian antara lain Javed, Iqbal, dan Hasan (2006), Abor dan Biekpe (2007), dan Andres (2007). Penelitian-penelitian tersebut menyatakan bahwa semakin baik perusahaan menerapkan tata kelola (mengikuti semua aspek yang ada dalam tata kelola perusahaan) sejalan dengan profitabilitas yang juga meningkat. Hal ini dikarenakan tata kelola perusahaan berfungsi untuk mengawasi dan mengontrol proses bisnis perusahaan sesuai dengan aspek-aspek dari tata kelola perusahaan (IFC dan OJK, 2014). Dengan sistem dan proses bisnis yang teratur, maka perusahaan dapat fokus dalam meningkatkan prof itabilitasnya. Akan tetapi, tidak semua penelitian membuktikan bahwa penerapan tata kelola perusahaan yang baik memberikan pengaruh positif terhadap profitabilitas. Vafeas (1999) dan Yermack (1996) membuktikan bahwa walaupun semakin baik perusahaan menerapkan tata kelola tetapi profitabilitas mengalami penurunan. 
Hasil-hasil penelitian yang belum konsisten mendorong penelitian ini untuk menganalisa lebih jauh pengaruh tata kelola perusahaan terhadap profitabilitas. Penelitian ini mengacu pada penelitian Zabri, Ahmad, dan Wah (2016) yang meneliti pengaruh penerapan tata kelola perusahaan terhadap profitabilitas perusahaan di Malaysia. Perbedaannya, penelitian ini menambahkan beberapa variabel selain ukuran dewan direksi dan komposisi komisaris independen antara lain; frekuensi rapat dewan komisaris, ukuran komite audit, frekuensi rapat komite audit umur perusahaan dan leverage sebagai variabel independen.

\section{Landasan Teori dan Pengembangan Hipotesis}

\section{Tata Kelola Perusahaan}

Good Governance atau tata kelola perusahaan menurut The Organization for Economic Cooperation and Development (OECD) (2015) versi G20/OECD Principles of Corporate Governance yang menyatakan bahwa internal perusahaan yang berkorporasi dalam menjalankan dan mengontrol perusahaan tersebut yang terlibat dalam mengatur hubungan antara manajemen perusahaan, direksi, pemegang saham dan pemangku kepentingan dalam perusahaan. Tata kelola perusahaan menyediakan struktur yang sesuai dengan tujuan dari perusahaan dan mencapai tujuan yang diinginkan sekaligus mengawasi kinerjanya. Tata kelola perusahaan juga dapat memfasilitasi adanya pengawasan yang efektif yang dapat mengawasi perusahaan dalam penggunaan sumber daya yang dimiliki. Selain itu, praktek tata kelola perusahaan merupakan salah satu mekanisme di dalam perusahaan untuk memitigasi agency problem.

Penerapan tata kelola yang baik juga menyediakan insentif yang sesuai untuk segala pemangku kepentingan dalam perusahaan untuk memberikan motivasi agar tujuan perusahaan dapat tercapai. Profitabilitas merupakan salah satu tujuan perusahaan. Hubungan penerapan tata kelola perusahaan dengan profitabilitas perusahaan dinyatakan oleh Darwis (2009) yang mengatakan bahwa profitabilitas perusahaan ditentukan dari tingkat keseriusan perusahaan dalam mengikuti peraturan tata kelola perusahaan. Hal ini dapat dikarenakan oleh dampak dari praktik tata kelola perusahaan yang dapat mengurangi resiko yang dilakukan oleh manajemen untuk memenuhi kepentingan pribadi 
serta meningkatkan kepercayaan investor untuk menanamkan modal yang dapat meningkatkan profitabilitas perusahaan. Pada penelitian ini, mekanisme tata kelola perusahaan dilihat dari ukuran dewan direksi, kompos isi dewan komisaris independen, frekuensi rapat dewan direksi, ukuran komite audit, dan frekuensi rapat komite audit.

\section{Pengembangan Hipotesis}

\section{Ukuran Dewan Direksi Terhadap Profitabilitas Perusahaan}

Berdasarkan peraturan Otoritas Jasa Keuangan Nomor 32/SEOJKT.04/2015 yang dike luarkan oleh OJK (2015), dewan direksi merupakan organ perusahaan yang memiliki kekuasaan untuk mengurus perusahaan dan bertanggung jawab untuk memenuhi kepentingan dan tujuan dari perusahaan. Ukuran dewan direksi dapat berbeda-beda di setiap negara karena adanya perbedaan kultur di masing-masing negara (Zabri et al., 2016). Berdasarkan Peraturan Otoritas Jasa Keuangan Nomor 33/POJK.04/2014 tentang Direksi dan Dewan Komisaris yang dikeluarkan oleh OJK (2014), ukuran dewan direksi di Indonesia harus memiliki paling sedikit dua anggota direksi dan harus bertindak sesuai dengan peraturan yang ditetapkan untuk dewan direksi.

Dewan direksi bertanggungjawab da lam menge lola perusahaan untuk memenuhi kepentingan dari perusahaan dan memastikan perusahaan dapat berjalan dengan baik (Nathania, 2014). Ukuran dewan direksi yang besar dianggap lebih unggul dibandingkan ukuran dewan direksi yang lebih kecil karena jumlah dewan direksi yang lebih banyak akan memiliki tingkat kapabilitas dan kompetensi yang lebih besar serta hubungan eksternal yang lebih luas (Amran, 2011). Hal tersebut menunjukkan bahwa semakin banyak direksi yang berada di dalam jajaran dewan direksi maka perusahaan akan lebih efektif dan efisien. Namun, penelitian dari Yermack (1996) mengatakan bahwa ukuran dewan direksi yang lebih kecil memberikan hasil yang lebih baik kepada kinerja perusahaan dibandingkan dengan ukuran dewan direksi yang besar. Abor dan Biekpe (2007) serta Al-matari et al. (2012) mengatakan bahwa kerugian dari memiliki dewan direksi yang berukuran besar adalah terjadinya kesalahpahaman dan koordinasi yang kurang baik di antara dewan direksi sehingga dapat 
menyebabkan kinerja manajemen menjadi kurang efektif dan dapat menimbulkan masalah di dalam perusahaan.

Dewan direksi merupakan agen yang bertanggungjawab untuk menjalankan kepentingan prinsipal. Namun, dengan semakin banyak anggota yang berada di dewan direksi maka resiko terjadinya konflik kepentingan akan semakin meningkat karena dewan direksi akan menjalankan kepentingan pribadi dibandingkan kepentingan dari prinsipal. Dewan direksi berpotensi untuk memanfaatkan sumber daya perusahaan untuk memenuhi kepentingan pribadi dan tidak menjalankan kepentingan perusahaan. Hal ini dapat menghambat efektivitas dan efisiensi dari perusahaan dan dapat menurunkan prof itabilitas perusahaan. Berdasarkan penelitian diatas dan juga melihat fenomena dari tata kelola perusahaan dan teori keagenan serta peraturan OJK mengenai dewan direksi, hipotesa yang dapat diambil adalah sebagai berikut:

H1: Ukuran dewan direksi memiliki pengaruh yang negatif terhadap profitabilitas perusahaan

\section{Komposisi Dewan Komsiaris Independen Terhadap Profitabilitas}

Peraturan Otoritas Jasa Keuangan No 33/POJK.04/2014 (OJK, 2014) menyatakan bahwa dewan komisaris merupakan organ perusahaan yang bertugas untuk melakukan pengawasan secara umum dan harus sesuai dengan ketentuan anggaran serta memberi nasihat kepada dewan direksi. Yasser (2011) menemukan bahwa jumlah komisaris independen yang lebih besar dapat meningkatkan prof itabilitas perusahaan karena komisaris independen dapat meningkatkan efektivitas perusahaan dan juga dapat mencegah terjadinya agency problem yang dapat terjadi di perusahaan. rgan mampu menja lankan fungsinya masing-masing secara efisien dan efektif.

Anderson dan Reeb (2004) menemukan bahwa komisaris independen memiliki pengaruh yang positif terhadap kinerja perusahaan. Hal ini disebabkan oleh peran dari komisaris independen yang bersikap netral dan dapat menjadi penengah dalam memecahkan masalah diantara pemegang saham yang menga lami konflik kepentingan. Penelitian dari Kyereboah-Coleman (2007) menemukan bahwa komposisi komisaris independen memiliki pengaruh yang signifikan negatif terhadap profitabilitas perusahaan yang berada di Afrika yang berarti bahwa semakin banyak komisaris 


\section{saki}

Studi Akuntansi \& Keuangan Indonesia

independen yang berada di dalam perusahaan maka kinerja perusahaan akan semakin menurun. Mayoritas komisaris independen di perusahaan Afrika dipilih oleh pemerintah karena ada banyak perusahaan di Afrika yang dimiliki negara. Kebijakan ini berdampak kepada profitabilitas perusahaan di Afrika karena tidak dapat memberikan hasil yang diharapkan karena komisaris independen dipilih hanya untuk memenuhi peraturan pemerintah sehingga kinerja perusahaan menjadi menurun.

Komisaris independen merupakan komisaris yang tidak terafiliasi dengan komisaris lainnya dan berperan sebagai pihak yang netral dan memastikan manajemen perusahaan dapat berjalan sesuai dengan peraturan dan regulasi yang berlaku. Adanya komisaris independen dapat meminimalisir terjadinya perbedaan kepentingan antara prinsipal dan agen di dalam perusahaan. Komisaris independen dibutuhkan untuk mengontrol tindakan dari direksi supaya tidak terjadi tindakan yang oportunistik serta meningkatkan efektivitas dari perusahaan. Maka dari itu, independensi perusahaan akan terjaga dari adanya tekanan dari orang-orang yang memiliki kepentingan pribadi dalam perusahaan. Berdasarkan penelitian diatas dan melihat fenomena tata kelola perusahaan dan teori keagenan serta peraturan OJK mengenai komisaris independen, hipotesa yang dapat diambil adalah sebagai berikut:

H2: Komposisi dewan komisaris independen memiliki pengaruh yang positif terhadap profitabilitas perusahaan

\section{Frekuensi Rapat Dewan Komisaris Terhadap Profitabilitas Perusahaan}

Rapat dewan komisaris dibutuhkan untuk mencari solusi terhadap masalah-masalah yang timbul dalam perusahaan. Peraturan tata kelola perusahaan mengharuskan dewan komisaris untuk mengadakan rapat secara reguler untuk membahas masalah-masalah yang timbul di perusahaan (Yasser, 2011). Yasser (2011) menemukan bahwa frekuensi rapat dewan komisaris memiliki pengaruh yang signifikan positif terhadap profitabilitas perusahaan yang terdaftar di Karachi Stock Exchange. Hal ini sejalan dengan penelitian yang dilakukan oleh Javed et al. (2006) yang menemukan frekuensi rapat dewan komisaris memiliki hubungan yang positif dalam meningkatkan profitabilitas dari perusahaan. Hal ini dikarenakan oleh banyaknya rapat yang dilakukan oleh dewan komisaris 
dapat membuat dewan komisaris untuk berdiskusi lebih banyak dan menemukan solusi yang terbaik untuk masalah-masalah yang dialami oleh perusahaan sehingga profitabilitas perusahaan akan semakin efektif dan semakin baik. Frekuensi rapat yang lebih banyak akan membutuhkan lebih banyak biaya sehingga sumber daya yang dimiliki oleh perusahaan akan teralokasi untuk melakukan rapat-rapat tersebut sehingga dapat menurunkan produktivitas dari perusahaan yang dapat berdampak ke profitabilitas perusahaan (Johl et al., 2015). Salah satu biaya yang dapat timbul dari diadakannya rapat dewan komisaris yang banyak adalah waktu yang dikorbankan oleh komisaris sehingga tidak dapat melakukan pengawasan yang efektif dan dapat menghambat efektivitas dari berjalannya perusahaan.

Meskipun rapat dewan komisaris memerlukan banyak biaya untuk diselenggarakan yang menyebabkan efektivitas perusahaan terhambat, ada beberapa keuntungan yang dapat diambil dengan melakukan rapat dewan komisaris yang salah satunya adalah komisaris memiliki waktu yang lebih banyak untuk berdiskusi dan menentukan strategi yang akan diterapkan untuk meningkatkan kinerja dari perusahaan (Vafeas, 1999). Selain itu, frekuensi rapat dewan komisaris dilakukan untuk berdiskusi mengenai kondisi perusahaan serta melakukan monitoring yang lebih baik lagi terhadap manajemen perusahaan sehingga tidak timbul masalah yang tidak diinginkan. Frekuensi rapat dewan komisaris dianggap sebagai cara yang diperlukan untuk meningkatkan efektivitas dari perusahaan dan juga dapat menjadi cara bagi dewan komisaris untuk mendapatkan informasi yang spesifik mengenai perusahaan sehingga dewan komisaris dapat melakukan monitoring dengan lebih baik lagi (Conger \& Lawler, 2009). Berdasarkan penelitian diatas dan fenomena tata kelola perusahaan serta peraturan OJK mengenai rapat dewan komisaris, hipotesa yang dapat ditarik adalah sebagai berikut:

H3: Frekuensi rapat dewan komisaris memiliki pengaruh positif terhadap profitabilitas perusahaan

\section{Ukuran Komite Audit Terhadap Profitabilitas Perusahaan}

Menurut Peraturan Otoritas Jasa Keuangan Nomor 33 /POJK.04/2014 (OJK, 2014), komite audit merupakan komite yang dibentuk oleh dewan komisaris untuk melaksanakan tugas dan tanggung jawab dari dewan komisaris. Kyereboah-Coleman (2007) menemukan ukuran komite audit 
memiliki pengaruh yang signifikan pos itif terhadap profitabilitas perusahaan dan ukuran komite audit merupakan indikator untuk melihat keseriusan perusahaan dalam hal pengungkapan dan transparansi perusahaan. Ukuran komite audit yang besar juga dapat meningkatkan kinerja perusahaan karena dapat memberikan hasil diskusi yang lebih detail kepada laporan keuangan perusahaan yang dapat meningkatkan kualitas dari laporan keuangan perusahaan sehingga dapat meningkatkan profitabilitas perusahaan (Danoshana \& Ravivathani, 2013). Penelitian dari Narwal dan Jindal (2015) menemukan bahwa semakin banyak anggota yang berada dalam komite audit maka profitabilitas perusahaan akan menurun karena komite audit akan mengalami masalah dalam pembagian tanggung jawab dan pengambilan keputusan yang dapat berdampak kepada efektivitas kinerja perusahaan. Karamanou dan Vafeas (2005) juga mengatakan bahwa perusahaan yang memiliki anggota komite audit yang banyak akan mengalami miskomunikasi dan pembagian tugas yang tidak jelas.

Menurut Peraturan Otoritas Jasa Keuangan Nomor 33 /POJK.04/2015 (OJK, 2014), komite audit bertanggung jawab untuk melakukan evaluasi terhadap informasi keuangan perusahaan serta memastikan perusahaan telah mengikuti peraturan yang berhubungan dengan kegiatan perusahaan. Adanya komite audit dapat mengurangi terjadinya perbedaan kepentingan karena komite audit bertugas untuk memastikan manajemen perusahaan telah mengikuti peraturan yang sudah ada dan tidak ada perilaku oportunistik yang dilakukan oleh agen untuk mendapatkan keuntungan pribadi. Maka dari itu, dengan adanya komite audit dalam perusahaan, perusahaan akan meningkatkan aspek responsibilitas perusahaan dalam mengikuti peraturan OJK yang sudah ada. Selain itu, komite audit juga berfungsi membantu dewan komisaris independen dalam meningkatkan independensi perusahaan dalam mencegah terjadinya tekanan dari orang-orang yang memaksakan kehendak. Berdasarkan penelitian diatas dan fenomena tata kelola perusahaan dan teori keagenan serta peraturan OJK mengenai komite audit, hipotesa yang dapat diambil adalah sebagai berikut:

H4: Ukuran komite audit memiliki pengaruh yang positif terhadap profitabilitas perusahaan 
Rapat komite audit diadakan untuk membahas masalah-masalah yang ada di dalam internal perusahaan seperti masalah keuangan dan masalah pelanggaran peraturan. Frekuensi rapat komite audit memegang peranan penting dalam memonitor efektivitas perusahaan karena pada saat rapat komite audit melakukan evaluasi terhadap kinerja dari manajemen perusahaan dan memastikan perusahaan telah menaati seluruh peraturan yang telah ditetapkan (Lin, Li \& Yang, 2006). Danoshana dan Ravivathani (2013) menemukan bahwa frekuensi rapat komite audit memiliki pengaruh yang signifikan negatif terhadap profitabilitas perusahaan. Penelitian ini menunjukkan bahwa semakin banyak rapat yang dilakukan oleh komite audit maka kinerja perusahaan akan menurun. Komite audit yang melakukan rapat lebih banyak akan berdampak kepada profitabilitas perusahaan yang akan menurun karena akan ada peningkatan da lam biaya yang dikeluarkan untuk melakukan rapat tersebut (Danoshana \& Ravivathani, 2013).

Rapat komite audit dibutuhkan untuk mengevaluasi manajemen perusahaan dalam hal pelaporan laporan keuangan dan ketaatan peraturan yang dapat meningkatkan kualitas dan efektivitas dari perusahaan. Al-matari et al. (2012) mengatakan bahwa rapat komite audit dilakukan untuk memonitor pengendalian internal dari perusahaan sehingga dapat memberikan informasi yang terpercaya kepada para pemangku kepentingan. Oleh karena itu, komite audit dapat memperkuat fungsi dari internal audit perusahaan dan melakukan evaluasi terhadap resiko bisnis yang dihadapi oleh manajemen sehingga dapat membuat perusahaan menjadi lebih efektif dan efisien. Rapat komite audit juga memberikan peningkatan dalam melakukan kontrol terhadap perusahaan sehingga transparansi perusahaan dapat menjadi lebih baik lagi. Berdasarkan penelitian diatas dan fenomena tata kelola perusahaan serta peraturan OJK mengenai rapat komite audit, hipotesa yang dapat diambil adalah sebagai berikut:

H5: Frekuensi rapat komite audit memiliki pengaruh positif terhadap profitabilitas perusahaan

\section{Kerangka Penelitian}

Berikut adalah kerangka penelitian yang digunakan dalam penelitian ini: 


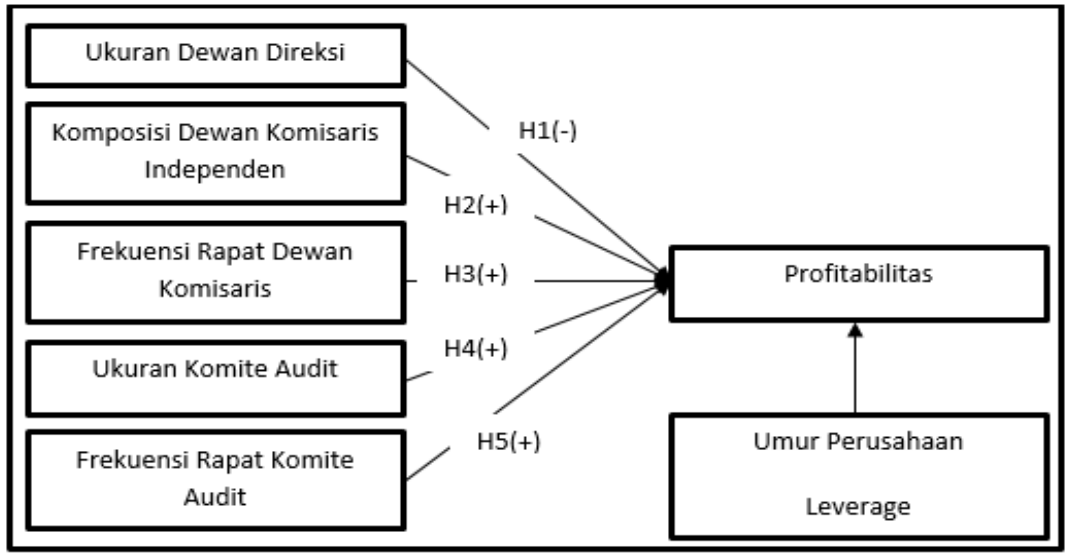

Gambar 1 Kerangka Penelitian

\section{Metode Penelitian}

\section{Data dan Pemilihan Sampel Penelitian}

Data yang akan digunakan dalam penelitian ini dibagi menjadi dua, yaitu pengambilan data melalui Capital $I Q$ dan laporan tahunan. Data-data yang diambil merupakan data dari laporan keuangan perusahaan yang telah terdaftar di dalam Bursa Efek Indonesia (BEI). Data keuangan diperoleh melalui laporan keuangan perusahaan yang telah tertera di Capital IQ. Sedangkan, data-data tata kelola perusahaan diperoleh melalui laporan tahunan perusahaan melalui situs website Bursa Efek Indonesia atau situs resmi perusahaan.

\section{Variabel Penelitian dan Definisi Operasional Variabel}

Penelitian ini bertujuan untuk menganalisa pengaruh tata kelola perusahaan terhadap profitabilitas perusahaan. Variabel tata kelola perusahaan yang digunakan adalah ukuran dewan direksi, komposisi komisaris independen, frekuensi dewan komisaris, ukuran komite audit, dan frekuensi rapat komite audit. Sedangkan, profitabilitas diukur menggunakan ROA dan ROE. Dalam penelitian ini, ada dua variabel kontrol yang digunakan, yaitu umur perusahaan dan leverage. 
Tabel 1: Tabel Operasionalisasi Variabel

\begin{tabular}{|l|l|l|l|}
\hline Variabel & Proksi & Formula & Sumber \\
\hline Profitabilitas & ROA & $\begin{array}{l}\text { ROA = Laba Bersih / } \\
\text { Total Aset }\end{array}$ & $\begin{array}{l}\text { Pengambilan data dari } \\
\text { capital IQ }\end{array}$ \\
\hline Profitabilitas & ROE & $\begin{array}{l}\text { ROE = Laba Bersih / } \\
\text { Total Equity }\end{array}$ & $\begin{array}{l}\text { Pengambilan data dari } \\
\text { capital IQ }\end{array}$ \\
\hline $\begin{array}{l}\text { Ukuran Dewan } \\
\text { Direksi }\end{array}$ & Jumlah Dewan Direksi & $\begin{array}{l}\text { Jumlah dewan direksi } \\
\text { dalam setahun }\end{array}$ & $\begin{array}{l}\text { Pengambilan data dari } \\
\text { annual report } \\
\text { perusahaan }\end{array}$ \\
\hline $\begin{array}{l}\text { Komposisi Dewan } \\
\text { komisaris }\end{array}$ & $\begin{array}{l}\text { Jumlah Dewan } \\
\text { Komisaris Independen }\end{array}$ & $\begin{array}{l}\text { Komisaris Independen / } \\
\text { Total Komisaris }\end{array}$ & $\begin{array}{l}\text { Pengambilan data dari } \\
\text { annual report } \\
\text { perusahaan }\end{array}$ \\
\hline $\begin{array}{l}\text { Frekuensi Rapat } \\
\text { Dewan Komisaris }\end{array}$ & $\begin{array}{l}\text { Jumlah Rapat Dewan } \\
\text { Komisaris }\end{array}$ & $\begin{array}{l}\text { Frekuensi rapat dewan } \\
\text { komisaris dalam } \\
\text { setahun }\end{array}$ & $\begin{array}{l}\text { Pengambilan data dari } \\
\text { annual report } \\
\text { perusahaan }\end{array}$ \\
\hline $\begin{array}{l}\text { Ukuran Komite } \\
\text { Audit }\end{array}$ & Jumlah Komite Audit & $\begin{array}{l}\text { Jumlah komite audit } \\
\text { dalam setahun }\end{array}$ & $\begin{array}{l}\text { Pengambilan data dari } \\
\text { annual report } \\
\text { perusahaan }\end{array}$ \\
\hline $\begin{array}{l}\text { Frekuensi Rapat } \\
\text { Komite Audit }\end{array}$ & $\begin{array}{l}\text { Jumlah rapat komite } \\
\text { audit dalam setahun }\end{array}$ & $\begin{array}{l}\text { Frekuensi rapat komite } \\
\text { audit dalam setahun }\end{array}$ & $\begin{array}{l}\text { Pengambilan data dari } \\
\text { annual report } \\
\text { perusahaan }\end{array}$ \\
\hline $\begin{array}{l}\text { Umur Perusahaan } \\
\text { berdirinya perusahaan }\end{array}$ & $\begin{array}{l}\text { Jumlah tahun dari } \\
\text { sejak mulai berdiri }\end{array}$ & $\begin{array}{l}\text { Total Liabilitas / Total } \\
\text { Aset } \\
\text { capital IQ }\end{array}$ & $\begin{array}{l}\text { Pengambilan data dari } \\
\text { capital IQ }\end{array}$ \\
\hline
\end{tabular}

\section{Model Penelitian}

Penelitian ini ingin melihat perbedaan dampak dari penerapan tata kelola perusahaan terhadap kinerja perusahaan. Model penelitian yang digunakan adalah model penelitian yang dilakukan oleh Amran (2011) untuk melihat pengaruh dari tata kelola perusahaan terhadap profitabilitas perusahaan. Namun, dalam penelitian ada beberapa variabel independen tambahan yang akan digunakan, antara lain frekuensi rapat dewan komisaris, ukuran komite audit, dan frekuensi rapat komite audit. Model penelitian yang akan digunakan dalam penelitian ini adalah sebagai berikut:

$$
\begin{aligned}
\text { PROFIT }_{i t}=\beta_{0} & +\beta_{1} \text { DSIZE }_{i t}+\beta_{2} \text { ICCOMPO }_{i t}+\beta_{3} \text { CMEETG }_{i t}+\beta_{4} \text { ACSIZE }_{i t}+\beta_{5} \text { ACMETG }_{i t} \\
& +\beta_{6} \text { FAGE }_{i t}+\beta_{7} L E V_{i t}
\end{aligned}
$$

Keterangan:

PROFIT : Profitabilitas perusahaan yang dinilai dari ROA dan ROE 
DSIZE $\quad$ : Jumlah Dewan Direksi

ICCOMPO :\% Komisaris Independen / Total Komisaris

CMEETG : Frekuensi rapat dewan komisaris dalam setahun

ACSIZE : Jumlah Komite Audit

ACMEETG : Frekuensi Rapat Komite Audit dalam Setahun.

FAGE $\quad$ : Umur perusahaan sejak mulai berdiri

LEV : Nilai total liabilitas dibagi dengan nilai total aset

\section{Metode Analisis}

Pengolahan data dan analisa untuk model penelitian ini menggunakan program stata 13. Sedangkan metode analisa terdiri dari statistik deskriptif, uji ketepatan model, uji asumsi klasik, dan uji hipotesis.

\section{Analisis Dan Pembahasan}

\section{Hasil Seleksi Sampel}

Sampel data dalam penelitian ini diambil dengan menggunakan kriteria: (1)Perusahaan termasuk sektor non-keuangan; (2) Perusahaan yang tidak memiliki nilai rasio keuangan yang negatif, yaitu ROA dan ROE; (3) Perusahaan memiliki kelengkapan annual report tahun 2012-2016. Bedasarkan data yang telah didapat, data perusahaan non-keuangan yang terdaftar di Bursa Efek Indonesia (BEI) berjumlah 438 perusahaan, sebanyak 68 perusahaan tidak memiliki kelengkapan laporan tahunan 2012-2016, dan 181 perusahaan memiliki rasio keuangan negatif. Sehingga, total observasi penelitian ini sebanyak 850 perusahaan.

\section{Statistik Deskriptif}

Tabel 2 merupakan hasil statistik deskriptif sampel penelitian. Rata-rata ROA setiap tahunnya adalah 7,69 persen artinya selama periode penelitian, perusahaan sampel berhasil mencatatkan keuntungan. Rata-rata ROE setiap tahunnya sebesar 14,52 persen, artinya tingkat efisiensi rata-rata 


\section{saki}

Studi Akuntansi \& Keuangan Indonesia

perusahaan di Indonesia dalam mengelola equity-nya untuk menghasilkan laba sebesar 14,52 persen.

Dari tabel 2 jugadapat terlihat bahwa rata-rata perusahaan di Indonesia memiliki 5 dewan direksi.

Tabel tersebut memperlihatkan bahwa rata-rata perusahaan di Indonesia memiliki komposisi komisaris independen sebesar 40,36 persen. Dari hasil statistik deskriptif memperlihatkan bahwa ratarata perusahaan melakukan rapat dewan komisaris sebanyak 5 kali da lam setahun. Sedangkan untuk komite audit, statistik deskriptif memperlihatkan rata-rata perusahaan memiliki komite audit sebanyak 3 orang. Di Indonesia, rata-rata perusahaan melakukan rapat komite audit sebanyak 5 kali selama setahun.

Tabel 2 Statistik De skriptif

\begin{tabular}{|l|r|r|r|r|}
\hline Statistik Deskriptif & \multicolumn{1}{|l|}{ Mean } & Std. Deviasi & \multicolumn{1}{l|}{ Min } & \multicolumn{1}{l|}{ Max } \\
\hline ROA & 0.0769 & 0.0755 & 0.0001 & 0.5767 \\
\hline ROE & 0.1452 & 0.1692 & 0.0002 & 2.0141 \\
\hline DSIZE & 5.2282 & 2.1044 & 2.0000 & 16.0000 \\
\hline ICCOMPO & 0.4036 & 0.1027 & 0.1667 & 0.8000 \\
\hline CMEETG & 5.0929 & 2.6064 & 0.0000 & 17.0000 \\
\hline ACSIZE & 3.0447 & 0.3733 & 0.0000 & 5.0000 \\
\hline ACMEETG & 5.4529 & 3.0281 & 0.0000 & 19.0000 \\
\hline FAGE & 35.3059 & 20.5066 & 4.0000 & 199.0000 \\
\hline LEV & 0.4312 & 0.1855 & 0.0002 & 0.9339 \\
\hline
\end{tabular}

Ket: ROA (Return on Asset); ROE (Return on Equity); DSIZE (Ukuran Dewan Direksi); ICCOMPO (Komposisi Dewan Komisaris Independen); CMEETG (Frekuensi Rapat Dewan Komisaris); ACSIZE (Ukuran Komite Audit); ACMEETG (Frekuensi Rapat Komite Audit); FAGE (Umur Perusahaan); LEV (Leverage).

Sumber: Data diolah (2017)

\section{Uji Hipotesis ROA}


Tabel 3 Hasil Regresi Menggunakan ROA

\begin{tabular}{|c|c|c|c|c|}
\hline Variabel & Coefficient & Std. Error & t & Prob. \\
\hline DSIZE & -0.0038357 & 0.000885 & -4.33 & $0.000^{* * *}$ \\
\hline LOGICCOMPO & 0.021729 & 0.005447 & 3.99 & $0.000^{* * *}$ \\
\hline CMEETG & -0.0012058 & 0.000501 & -2.41 & $0.017^{* *}$ \\
\hline ACSIZE3 & -0.0001084 & $3.36 E-05$ & -3.22 & $0.002^{* * *}$ \\
\hline ACMEETG & -0.0019098 & 0.000231 & -8.28 & $0.000^{* * *}$ \\
\hline FAGE & -0.0069088 & 0.00083 & -8.32 & $0.000^{* * *}$ \\
\hline LEV & -0.0993876 & 0.018528 & -5.36 & $0.000^{* * *}$ \\
\hline cons & 0.4190441 & 0.037117 & 11.29 & 0.000 \\
\hline Prob > F = 0.0000 & & & \\
\hline R-squared within $=\mathbf{0 . 1 1 4 7}$ \\
\hline *: Signifikan pada 10\% & *: Signifikan pada 5\% \\
\hline ***: Signifikan pada 1\% & \\
\hline
\end{tabular}

Ket: ROA (Return on Asset); ROE (Return on Equity); DSIZE (Ukuran Dewan Direksi); ICCOMPO (Komposisi Dewan Komisaris Independen); CMEETG (Frekuensi Rapat Dewan Komisaris); ACSIZE (Ukuran Komite Audit); ACMEETG (Frekuensi Rapat Komite Audit); FAGE (Umur Perusahaan); LEV (Leverage).

Sumber: Data diolah (2017)

Model ini menguji pengaruh variabel independen terhadap ROA sebagai pengukur profitabilitas. Pada model ini, R-square yang dihasilkan adalah 0,1147 atau 11,47 persen. Hal ini menunjukan bahwa variabel independen dapat menje laskan variabel dependen sebesar 11,47 persen terhadap ROA. Model ini juga menggambarkan bahwa semua variabel independen dan variabel kontrol memberikan pengaruh signifikan terhadap ROA. Komposisi komisaris independen memberikan pengaruh signifikan positif terhadap ROA, sedangkan variabel lainnya berpengaruh negatif signifikan terhadap ROA. Pengaruh signifikan tersebut dapat dilihat dari uji F dan uji T.

\section{Uji Hipotesis ROE}

Model dibawah ini menguji pengaruh variabel independen terhadap ROE sebagai pengukur profitabilitas. Hasil R-square yang dihasilkan pada uji hipotesis menggunakan ROE sebesar 0,1162. Hal ini menunjukkan bahwa variabel independen memiliki pengaruh sebesar 11,62 persen terhadap ROE. Hasil uji $\mathrm{F}$ menunjukkan variabel independen dan variabel kontrol berdampak signifikan terhadap profitabilitas yang diukur menggunakan ROA. Hasil uji t pun memperlihatkan hasil yang sama. Setiap variabel independen dan variabel kontrol memberikan pengaruh signifikan terhadap 


\section{saki}

Studi Akuntansi \& Keuangan Indonesia

ROA maupun ROE. Ukuran dewan direksi, frekuensi rapat dewan komisaris, ukuran komite audit, frekuensi rapat komite audit, dan umur perusahaan memberikan pengaruh signifikan negatif terhadap ROE. Sedangkan komposisi dewan komisaris independen dan leverage memberikan pengaruh signifikan positif terhadap ROE.

Tabel 4.12 Hasil Regresi Menggunakan ROE

\begin{tabular}{|c|c|c|c|c|}
\hline Variabel & Coefficient & Std. Error & t & Prob. \\
\hline DSIZE & -0.0061691 & 0.001285 & -4.80 & $0.000^{* * *}$ \\
\hline LOGICCOMPO & 0.0447145 & 0.016164 & 2.77 & $0.006^{* * *}$ \\
\hline CMEETG & -0.0019873 & 0.00039 & -5.09 & $0.000^{* * *}$ \\
\hline ACSIZE3 & -0.0003405 & $4.38 \mathrm{E}-05$ & -7.77 & $0.000^{* * *}$ \\
\hline ACMEETG & -0.0030209 & 0.000407 & -7.42 & $0.000^{* * *}$ \\
\hline FAGE & -0.0106533 & 0.00101 & -10.55 & $0.000^{* * *}$ \\
\hline LEV & 0.1355052 & 0.028061 & 4.83 & $0.000^{* * *}$ \\
\hline Cons & 0.5576788 & 0.052791 & 10.56 & 0.000 \\
\hline Prob > F = 0.0000 & & & \\
\hline R-squared within $=0.1162$ \\
\hline *: Signifikan pada 10\% & * : Signifikan pada 5\% & \\
\hline ***: Signifikan pada 1\%
\end{tabular}

Ket: ROA (Return on Asset); ROE (Return on Equity); DSIZE (Ukuran Dewan Direksi); ICCOMPO (Komposisi Dewan Komisaris Independen); CMEETG (Frekuensi Rapat Dewan Komisaris); ACSIZE (Ukuran Komite Audit); ACMEETG (Frekuensi Rapat Komite Audit); FAGE (Umur Perusahaan); LEV (Leverage).

Sumber: Data diolah (201/)

\section{Pembahasan}

\section{Pengaruh Ukuran Dewan Direksi Terhadap Profitabilitas}

Berdasarkan hasil regresi, ukuran dewan direksi memberikan pengaruh negatif signifikan terhadap profitabilitas perusahaan. Maka dari itu, hasil uji regresi menerima hipotesa 1 . Hasil ini memperlihatkan bahwa semakin banyak dewan direksi yang dimiliki berpengaruh terhadap penurunan profitabilitas. Hal ini dapat disebabkan oleh konflik-konflik yang muncul seiring bertambahnya anggota dewan direksi. Konflik yang dapat terjadi di antara dewan direksi adalah kesalahpahaman dan miskomunikasi dalam menjalankan keberlangsungan bisnis. Pernyataan ini sesuai dengan hasil penelitian yang dinyatakan oleh Nathania (2014) yaitu ukuran dewan direksi yang besar akan 
Studi Akuntansi \& Keuangan Indonesia

memperburuk profitabilitas perusahaan karena akan lebih sering terjadi miskomunikasi dan kesalahpahaman. Hal ini dikarenakan semakin banyak dewan direksi akan muncul banyak gagasan. Namun, gagasan yang diutarakan oleh seseorang akan membutuhkan waktu untuk penyamaan persepsi dan sudut pandang dalam proses pemberian gagasan tersebut. Jika semakin banyak direksi yang ada di dalam manajemen perusahaan, maka waktu yang dibutuhkan juga akan semakin lama untuk mengambil keputusan sehingga tidak efisien.

Banyaknya direksi juga dapat menyebabkan konflik lain, yaitu lebih mengutamakan kepentingan pribadi dibandingkan kepentingan perusahaan. Hal ini sesuai dengan teori keagenan (Jensen dan Meckling, 1976) yang menyatakan bahwa pemilik perusahaan dan manajer sering berbeda tujuan. Maka dari itu, kesempatan manajer untuk menggunakan sumber daya yang dimiliki perusahaan untuk kepentingan pribadi lebih besar untuk terjadi. Pernyataan ini juga sejalan dengan penelitian dari Yermack (1996) yang menyatakan bahwa jumlah dewan direksi yang banyak akan memperburuk profitabilitas perusahaan karena dewan direksi cenderung tidak menggunakan aset dan sumber daya lainnya secara efisien untuk mengoptimalkan prof itabilitas perusahaan.

\section{Pengaruh Komposisi Dewan Komisaris Independen Terhadap Profitabilitas Perusahaan}

Hasil regresi penelitian ini menunjukkan bahwa komposisi komisaris independen memberikan pengaruh positif signifikan terhadap profitabilitas perusahaan. Maka dari itu, hasil uji regresi menerima hipotesa 2. Hasil ini memperlihatkan bahwa semakin banyak komisaris independen yang berada di dalam dewan komisaris memberikan peningkatan terhadap profitabilitas perusahaan. Hal ini mungkin dapat terjadi karena dewan komisaris independen adalah pihak yang netral di dalam perusahaan. Sikap netral yang berada di dalam dewan komisaris independen dapat terjadi karena setiap dewan komisaris independen tidak diperbolehkan mendapat keuntungan dari perusahaan. Seperti yang dinyatakan dalam IFC dan OJK (2014), Indonesia Corporate Governance Manual menyatakan bahwa dewan komisaris independen tidak diperbolehkan mendapat keuntungan finansial atau keuntungan lainnya dari perusahaan dalam kurun waktu tiga tahun terakhir. Hal ini menunjukkan bahwa dewan komisaris independen merupakan orang yang berasal dari luar perusahaan dan tidak memiliki kepentingan pribadi di dalam perusahaan tersebut, sehingga dewan komisaris independen 
dapat meminimalisir adanya konflik kepentingan yang terjadi di dalam manajemen agar aspek independensi perusahaan dapat terjaga dan setiap organ perusahaan dapat menjalankan fungsinya masing-masing untuk mencapai tujuan perusahaan. Agar hal ini dapat terealisasi di dalam perusahaan, maka dibutuhkan dewan komisaris independen yang dapat menjalankan fungsinya dengan baik.

Fungsi dewan komisaris independen dalam rangka mencegah terjadinya konflik diperkuat oleh pernyataan dari Yasser (2011) yang menyatakan bahwa dewan komisaris independen dapat meningkatkan efektivitas perusahaan dengan melakukan pengawasan dan pencegahan terhadap tindakan oportunistik yang di lakukan oleh manajemen perusahaan. Selain itu, tidak adanya kepentingan di dalam perusahaan dapat memberikan pengaruh baik bagi dewan komisaris independen agar dewan komisaris independen fokus untuk menjalankan fungsinya. Pengaruh baik yang dihasilkan oleh dewan komisaris independen juga diperkuat oleh peraturan OJK, yaitu Salinan Surat Edaran Otoritas Jasa Keuangan Nomor 32 / SEOJK.04 / 2015 (OJK,2015) menyatakan bahwa dewan komisaris independen berfungsi untuk memberikan pengawasan dan mengontrol keberlangsungan bisnis perusahaan. Jika pengawasan dan pengontrolan dilakukan dengan baik, maka sistem operasional perusaahaan menjadi efektif dan efisien yang dapat meningkatkan profitabilitas perusahaan. Pernyataan ini diperkuat oleh penelitian Khan dan Awan (2012) dengan menyatakan bahwa kehadiran komisaris independen membuat perusahaan memiliki kontrol dan pengawasan yang baik sehingga tujuan perusahaan dapat tercapai.

Selain berfungsi sebagai pengawas dan pengontrol sistem operasional perusahaan, dewan komisaris juga berfungsi sebagai penengah untuk meredakan konflik di antara manajemen perusahaan karena dewan komisaris independen tidak memiliki kepentingan di dalam perusahaan, sehingga konflik yang terjadi tidak menghambat efektivitas perusahaan. Hal ini diperkuat oleh penelitian Anderson dan Reeb (2004) yang menyatakan bahwa semakin banyak komisaris independen memberikan pengaruh positif terhadap profitabilitas perusahaan karena dewan komisaris bersikap netral untuk memecahkan masalah di dalam perusahaan sehingga efektivitas perusahaan tidak terhambat.

\section{Pengaruh Frekuensi Rapat Dewan Komisaris Terhadap Profitabilitas Perusahaan}


Hasil regresi yang telah dilakukan menunjukkan bahwa frekuensi rapat dewan komisaris memberikan pengaruh negatif signifikan terhadap profitabilitas yang diukur dengan ROA dan ROE. Maka dari itu, hasil uji regresi menolak hipotesa 3. Hal ini mungkin dapat terjadi karena banyaknya sumber daya yang dike luarkan oleh perusahaan yang dialokasikan untuk rapat. Hal ini diperkuat oleh penelitian Johl et al. (2015) yang menyatakan bahwa semakin banyak rapat yang dilakukan akan membutuhkan biaya lebih banyak sehingga sumber daya yang dimiliki oleh perusahaan akan teralokasi untuk melakukan rapat.

Salah satu biaya yang menghambat efektivitas perusahaan adalah waktu manajemen yang terbuang untuk mengadakan rapat (Johl et al., 2015). Hal ini dikarenakan jika rapat dilakukan terus menerus tanpa realisasi yang dija lankan maka rapat tersebut akan menjadi aktivitas yang menghambat efektivitas perusahaan. Jika rapat dilakukan terus menerus, fungsi dewan komisaris dalam mengawasi dan mengontrol proses bisnis perusahaan akan menjadi terhambat, sehingga efektivitas perusahaan juga akan terganggu. Hal ini diperkuat dengan penelitian Vafeas (1999) yang menyatakan bahwa rapat menghambat efektivitas perusahaan karena keterbatasan waktu pada saat rapat membuat kontribusi dewan komisaris yang diberikan menjadi tidak optimal dan efektif.

\section{Pengaruh Ukuran Komite Audit Terhadap Profitabilitas Perusahaan}

Hasil regresi yang telah dilakukan menunjukkan bahwa semakin banyak komite audit dalam perusahaan memberikan penurunan kepada profitabilitas perusahaan. Maka dari itu, hasil uji regresi menolak hipotesa 4. Hal ini dapat disebabkan karena komite audit dibentuk hanya untuk memenuhi regulasi yang dibuat oleh pemerintah sehingga menjadi tidak efektif (Istighfarin \& Wirawati, 2015). Selain itu, karena komite audit dibatasi dengan fungsinya sebagai alat bantu dari dewan komisaris maka komite audit tidak memiliki wewenang secara langsung dalam pengawasan pengelolaan perusahaan. Hasil yang negatif signifikan tersebut menunjukkan bahwa semakin banyak anggota komite audit yang berada di dalam manajemen maka profitabilitas perusahaan akan menurun. Hasil tersebut sejalan penelitian dari Narwal dan Jindal (2015) yang menemukan semakin banyak anggota komite akan menurunkan profitabilitas perusahaan karena komite audit akan mengalami masalah dalam pembagian tanggung jawab dan akan terjadi miskomunikasi yang dapat menyebabkan kinerja 
dari komite audit menjadi tidak efektif. Karamanou dan Vafeas (2005) juga mengatakan komite audit dapat menjadi tidak efektif jika terdapat banyak anggota di dalam perusahaan karena akan mengalami kesulitan dalam proses pengambilan keputusan.

\section{Pengaruh Frekuensi Rapat Komite Audit Terhadap Profitabilitas Perusahaan}

Berdasarkan hasil regresi yang telah dilakukan, frekuensi rapat komite audit memberikan pengaruh signifikan negatif terhadap profitabilitas perusahaan. Sehingga, hasil uji regresi menolak hipotesa 5. Komite audit yang memiliki anggota yang banyak dapat memperburuk profitabilitas perusahaan karena akan membuat monitoring serta kinerja komite audit menjadi kurang efektif (Vafeas, 1999). Hal tersebut dapat berdampak kepada rapat yang diselenggarakan oleh komite audit karena semakin banyak anggota yang berada di dalam komite audit berarti akan ada semakin banyak sumber daya yang dapat dimanfaatkan. Namun, miskomunikasi dan hambatan-hambatan juga dapat muncul dalam rapat komite audit serta proses pengambilan keputusan.

Berdasarkan hasil uji hipotesa yang telah dilakukan, ditemukan frekuensi rapat komite audit memiliki pengaruh yang negatif signifikan terhadap profitabilitas perusahaan yang menandakan semakin banyak komite audit mengadakan rapat maka profitabilitas perusahaan akan menurun. Jika jumlah pertemuan komite audit tidak diiringi oleh kualitas yang dihasilkan oleh komite audit, maka frekuensi rapat komite audit akan menjadi tidak efektif dan dapat mempengaruhi prof itabilitas perusahaan. Selain itu, komite audit dibentuk hanya untuk memenuhi peraturan yang ada (Istighfarin \& Wirawati, 2015). Hal ini dapat membuat proses pemilihan dan kualifikasi untuk memilih anggota komite audit menjadi tidak maksimal. Jika anggota komite audit tidak memiliki keahlian dan pengalaman yang cukup maka rapat dapat menjadi tidak efektif dan dapat mempengaruhi profitabilitas perusahaan. Meskipun rapat komite audit berfungsi untuk memonitor proses pelaporan keuangan dan pengendalian internal perusahaan. Hasil ini sejalan dengan penelitian dari Danoshana dan Ravivathani (2013) yang menemukan frekuensi rapat komite audit memiliki pengaruh negatif kepada profitabilitas perusahaan. Hal tersebut dapat disebabkan oleh semakin banyak rapat komite audit yang diselenggarakan maka akan ada lebih biaya yang dikeluarkan dan sumber daya yang teralokasikan untuk rapat sehingga dapat menurunkan prof itabilitas perusahaan. 
Biaya yang menjadi dampak yang signif ikan terhadap profitabilitas perusahaan adalah waktu yang dikorbankan untuk mengadakan rapat. Hal ini seja lan dengan pernyataan Johl et al. (2015) yang menyatakan bahwa semakin banyak rapat yang dilakukan akan membutuhkan biaya yang lebih banyak. Biaya yang paling memberikan pengaruh untuk mengambat efektivitas perusahaan adalah waktu manajemen yang terbuang untuk rapat. Hal ini akan berdampak terhadap profitabilitas perusahaan karena jika komite audit melakukan rapat terus menerus, maka fungsi komite audit dalam mengawasi proses pelaporan keuangan yang dilakukan perusahaan akan menjadi terhambat. Hal ini dapat mengganggu efektivitas perusahaan.

\section{Kesimpulan, Implikasi, dan Keterbatasan}

Penelitian ini bertujuan untuk menganalisa adanya pengaruh dari penerapan tata kelola perusahaan di Indonesia terhadap profitabilitas perusahaan. Hal ini dilakukan karena tata kelola perusahaan berfungsi untuk mengontrol dan mengawasi keberlangsungan bisnis perusahaan serta memastikan perusahaan mengikuti peraturan yang diberlakukan oleh pemerintah. Penerapan tata kelola perusahaan juga akan meminimalisir terjadi konflik kepentingan di dalam manajemen. Maka dari itu, tata kelola perusahaan merupakan bagian penting di dalam keberlangsungan perusahaan. Dalam penelitian ini ada lima variabel yang digunakan, yaitu ukuran dewan direksi, komposisi komisaris independen, frekuensi rapat dewan komisaris, ukuran komite audit, dan frekuensi rapat komite audit. Kelima variabel tersebut memberikan pengaruh signifikan terhadap profitabilitas perusahaan.

Penelitian ini dapat dijadikan sebagai salah satu pertimbangan dalam pengambilan keputusan bagi investor ketika ingin menanamkan saham di suatu perusahaan. Para investor dapat menggunakan hasil penelitian ini sebagai salah satu sumber untuk pertimbangan para investor dalam mengambil keputusan. Hal ini dapat menjadi pertimbangan bagi investor karena penerapan tata kelola perusahaan dapat memberikan pengaruh terhadap profitabilitas perusahaan. Penelitian ini juga dapat menjadi acuan bagi penelitian selanjutnya dan memperkaya literature yang telah ada. 
Keterbatasan yang ditemukan dalam penelitian ini adalah penelitian ini hanya menganalisa berdasarkan data-data yang berasal dari laporan keuangan dan laporan tahunan. Akan tetapi, penelitian ini tidak dapat menganalisa hal yang berhubungan dengan hal kualitatif, seperti kualitas dari hasil rapat yang diadakan. Rekomendasi dan saran yang dianjurkan untuk penelitian selanjutnya adalah peneliti selanjutnya sebaiknya melakukan studi kasus pada suatu perusahaan. Hal ini bertujuan agar penelitian dapat memperlihatkan secara lebih mendalam dampak yang terjadi terhadap perusahaan tersebut dari penerapan tata kelola perusahaan yang telah dilakukan dan melihat keseriusan dan ketaatan perusahaan dalam menerapkan tata kelola perusahaan dengan peraturan yang telah dibuat oleh pemerintah. Selain itu, penelitian selanjutnya sebaiknya memperhatikan perbedaan tahun untuk manfaat yang dihasilkan tata kelola bagi perusahaan. Hal ini dikarenakan manfaat tata kelola akan memberikan efek bagi perusahaan dalam jangka panjang bukan jangka pendek.

\section{Daftar Pusaka}

Abor, J., \& Biekpe, N. (2007). Corporate Governance, Ownership Structure and Performance of SMEs in Ghana: Implications for Financing Opportunities. Corporate Governance: The International Journal of Business in Society, 7(3), 288-300.

Al-Matari, Y. A., Al-Swidi, A. K., Fadzil, F. H. B., Fadzil, H., \& Al-Matari, E. M. (2012). Board of Directors, Audit Committee Characteristics and The Performance of Saudi Arabia Listed Companies. International Review of Management and Marketing, 2(4), 241.

Amran, N. A. (2011). Corporate Governance Mechanisms and Company Performance: Evidence from Malaysian companies. International Review of Business Research Papers, 7(6), 101-114.

Anderson, R. C., \& Reeb, D. M. (2004). Board composition: Balancing family influence in S\&P 500 firms. Administrative Science Quarterly, 49(2), 209-237.

Andres, C. (2008). Large Shareholders and Firm Performance-An Empirical Examination of Founding-family Owners hip. Journal of Corporate Finance, 14(4), 431-445.

Conger, J., \& Lawler, E. E. (2009). Sharing Leadership On Corporate Boards: A Critical Requirement for Teamwork At The Top.

Danoshana, S. dan Ravivathani, T. (2013). The Impact of The Corporate Governance on Firm Perfomance: A Study on Financial Institutions in Sri Lanka. Merit Research Journals, Vol. 1(6), pp. 118-121.

Darwis, H. (2009). Corporate Governance Terhadap Kinerja Perusahaan. Jurnal Keuangan dan Perbankan, 13(3), 418-430.

International Finance Corporation \& Otoritas Jasa Keuangan (2014). The Indonesian Corporate Governance Manual, First Edition. from https://www.ifc.org/wps/wcm/connect/64185f0042cc3ab0b 145fd384c61d9f7/Indonesia CG Manual Feb2014.pdf?MOD=AJPERES

Istighfarin, D., \& Wirawati, N. G. P. (2015). Pengaruh Good Corporate Governance Terhadap Profitabilitas pada Badan Usaha Milik Negara (BUMN). E-Jurnal Akuntansi, 13(2), 564-581.

Javed, A. Y., Iqbal, R., \& Hasan, L. (2006). Corporate Governance and Firm Performance: Evidence from Karachi Stock Exchange [with comments]. The Pakistan Development Review, 947-964.

Jensen, M. C., \& Meckling, W. H. (1976). Theory of the firm: Managerial Behavior, Agency Costs and Ownership Structure. Journal of Financial Economics, 3(4), 305-360.

Johl, S. K., Kaur, S., \& Cooper, B. J. (2015). Board Characteristics and Firm Performance: Evidence from Malaysian Public Listed Firms. Journal of Economics, Business and Management, 3(2), 239-243. 


\section{saki}

Studi Akuntansi \& Keuangan Indonesia

Karamanou, I., \& Vafeas, N. (2005). The Association Between Corporate Boards, Audit Committees, and Management Earnings Forecasts: An Empirical Analysis. Journal of Accounting research, 43(3), 453486.

Khan, A., \& Awan, S. H. (2012). Effect of Board Composition On Firm's Performance: A Case of Pakistani Listed Companies. Interdisciplinary Journal of Contemporary Research in Business, 3(10), 853-863.

Komite Nasional Kebijakan Governance (2006), Pedoman Umum Good Corporate Governance Indonesia, Komite Nasional Kebijakan Governance, Indonesia. www.ecgi.org/codes/documents/indonesia cg $2006 \mathrm{id.pdf}$

Kyereboah-Coleman, A. (2008). Corporate Governance and Firm Performance in Africa: A Dynamic Panel Data Analysis. Studies in Economics and Econometrics, 32(2), 1-24.

Lin, J. W., Li, J. F., \& Yang, J. S. (2006). The Effect of Audit Committee Performance on Earnings Quality. Managerial Auditing Journal, 21(9), 921-933.

Lukviarman, N. (2016). Corporate Governance: Menuju Penguatan Konseptual Dan Implementasi Di Indonesia. Solo, Indonesia: PT Era Adicitra Intermedia

Nathania, A. (2014). Pengaruh Komposisi Dewan Perusahaan Terhadap Profitabilitas Perusahaan. Finesta, 2(1), 76-81.

Narwal, K. P., \& Jindal, S. (2015). The Impact of Corporate Governance on The Profitability: An Empirical Study of Indian Textile Industry. International Journal of Research in Management, Science \& Technology, 3(2), 81-85.

OECD (2015), G20/OECD Principles of Corporate Governance, OECD Publishing, Paris.http://dx.doi.org/10.1787/9789264236882-en.

Otoritas Jasa Keuangan (2014), Peraturan Otoritas Jasa Keuangan Nomor 33 / POJK.04 / 20 14. Retrived from www.ojk.go.id/Files/regulasi/ojk/pojk/pojk33.penjelasan.pdf

Otoritas Jasa Keuangan (2015), Surat Edaran Otoritas Jasa Keuangan Nomor 32 / SEOJK.04 / 2015. Retrived from http://www.ojk.go.id/id/kanal/pasar-modal/regulasi/otoritas-jasa-keuangan/surat-edaran-ojk-dandewan-ko misioner/Pages/seojk-No mor-32-04-2015-Pedoman-Tata -Kelola-Perusahaan.as px

Sukamulja, S. (2005). Good Corporate Governance di Sektor Keuangan: Dampak GCG Terhadap Kinerja Perusahaan (Kasus di Bursa Efek Jakarta). Benefit, 8(1), 1-25.

Vafeas, N. (1999). Board Meeting Frequency and Firm Performance. Journal of Financial Economics, 53(1), 113-142.

Yasser, Q. R. (2011). Corporate Governance and Firm Performance: An Analysis of Family and Non-family Controlled Firms. The Pakistan Development Review, 47-62.

Yermack, D. (1996). Higher Market Valuation of Companies With a Small Board of Directors. Journal of Financial Economics, 40(2), 185-211.

Zabri, S. M., Ahmad, K., \& Wah, K. K. (2016). Corporate Governance Practices and Firm Performance: Evidence from Top 100 Public Listed Companies in Malaysia. Procedia Economics and Finance, 35, 287-296. 